\title{
Temperature response measurements from eucalypts give insight into the impact of Australian isoprene emissions on air quality in $\mathbf{2 0 5 0}$
}

\author{
Kathryn M. Emmerson' ${ }^{1}$, Malcolm Possell ${ }^{2}$, Michael J. Aspinwall ${ }^{3,4}$, Sebastian Pfautsch ${ }^{3}$, and Mark G. Tjoelker ${ }^{3}$ \\ ${ }^{1}$ Climate Science Centre, CSIRO Oceans and Atmosphere, Aspendale, VIC 3195 Australia \\ ${ }^{2}$ School of Life and Environmental Sciences, University of Sydney, Sydney, NSW, Australia \\ ${ }^{3}$ Hawkesbury Institute for the Environment, Western Sydney University, Penrith, NSW, Australia \\ ${ }^{4}$ Department of Biology, University of North Florida, Jacksonville, Florida 32224, USA
}

Correspondence: Kathryn Emmerson (kathryn.emmerson@csiro.au)

Received: 28 January 2020 - Discussion started: 3 February 2020

Revised: 6 April 2020 - Accepted: 27 April 2020 - Published: 28 May 2020

\begin{abstract}
Predicting future air quality in Australian cities dominated by eucalypt emissions requires an understanding of their emission potentials in a warmer climate. Here we measure the temperature response in isoprene emissions from saplings of four different Eucalyptus species grown under current and future average summertime temperature conditions. The future conditions represent a 2050 climate under Representative Concentration Pathway 8.5, with average daytime temperatures of $294.5 \mathrm{~K}$. Ramping the temperature from 293 to $328 \mathrm{~K}$ resulted in these eucalypts emitting isoprene at temperatures $4-9 \mathrm{~K}$ higher than the default maximum emission temperature in the Model of Emissions of Gases and Aerosols from Nature (MEGAN). New basal emission rate measurements were obtained at the standard conditions of $303 \mathrm{~K}$ leaf temperature and $1000 \mu \mathrm{mol} \mathrm{m}{ }^{-2} \mathrm{~s}^{-1}$ photosynthetically active radiation and converted into landscape emission factors. We applied the eucalypt temperature responses and emission factors to Australian trees within MEGAN and ran the CSIRO Chemical Transport Model for three summertime campaigns in Australia. Compared to the default model, the new temperature responses resulted in less isoprene emission in the morning and more during hot afternoons, improving the statistical fit of modelled to observed ambient isoprene. Compared to current conditions, an additional $2 \mathrm{ppb}$ of isoprene is predicted in 2050, causing hourly increases up to $21 \mathrm{ppb}$ of ozone and 24-hourly increases of $0.4 \mu \mathrm{g} \mathrm{m}^{-3}$ of aerosol in Sydney. A $550 \mathrm{ppm} \mathrm{CO}_{2}$ atmosphere in 2050 mitigates these peak Sydney ozone mixing ratios by
\end{abstract}

$4 \mathrm{ppb}$. Nevertheless, these forecasted increases in ozone are up to one-fifth of the hourly Australian air quality limit, suggesting that anthropogenic $\mathrm{NO}_{x}$ should be further reduced to maintain healthy air quality in future.

\section{Introduction}

Biogenic volatile organic compounds (BVOCs) are emitted by vegetation in response to external stressors such as heat, light and herbivory (Sharkey and Monson, 2017). There are hundreds of individual BVOCs all exhibiting different emission behaviours (e.g. with or without a light dependence), but the largest global flux of a single BVOC is isoprene (2-methyl-1,3-butadiene; $\mathrm{C}_{5} \mathrm{H}_{8}$ ), with an estimated $440-600 \mathrm{Tg} \mathrm{C} \mathrm{yr}^{-1}$ (Guenther et al., 2012). Isoprene reacts rapidly in the atmosphere, contributing to ozone $\left(\mathrm{O}_{3}\right)$ and secondary organic aerosol (SOA) formation. For cities surrounded by forests, BVOC emissions can dominate airsheds, contributing to peak summertime ozone (Utembe et al., 2018) and early morning ozone spikes (Millet et al., 2016) if not quenched by the hydroxyl radical $(\mathrm{OH})$ on the previous day.

In addition to the different environmental reasons a plant will emit BVOCs, plants emit their own unique signature of BVOCs with varying strengths, even amongst plants in the same genus. Native to Australia, eucalypt trees are amongst the highest BVOC emitters of any plant species (Evans et al., 
1982; Benjamin et al., 1996; Kesselmeier and Staudt, 1999), emitting isoprene constitutively and storing monoterpenes within oil reservoirs in the leaves (Brophy et al., 1991). However, very few of the 800 species in the Eucalyptus genus (Department of Agriculture and Water Resources, 2018) have been studied for emissions. This is problematic as biogenic modellers tend to base simulations on a few measurements which represent a fraction of the potential diversity of species and emission rates. For example, the Eucalyptus isoprene emission factors for the Model of Emissions of Gases and Aerosols from Nature (MEGAN) were based on six studies, only one of which was conducted in Australia (see Emmerson et al., 2016). The Australian study measured large differences of $63 \mu \mathrm{gg}^{-1} \mathrm{~h}^{-1}$ of isoprene between the lowest- and highest-emitting eucalypt species, with E. globulus showing the greatest emission rates (He et al., 2000). Natural occurrence of E. globulus is restricted to temperate south-east Australia (including Tasmania).

Use of landscape emission factors (LEFs) weighted by higher-emitting trees has caused over-predictions in modelled isoprene (Emmerson et al., 2016, 2019a). As young leaves tend to emit more isoprene than older leaves, conducting emission measurements on saplings has been questioned (Street et al., 1997), although adult trees will contain a mixture of leaf ages. However, BVOC emission models such as MEGAN require isoprene emission rates to be determined at standard conditions of $303 \mathrm{~K}$ and $1000 \mu \mathrm{mol} \mathrm{m}^{-2} \mathrm{~s}^{-1}$ photosynthetically active radiation (PAR) (Guenther et al., 2012). Measurements made at other temperatures and PAR fluxes need scaling to these standard conditions, which can introduce uncertainties of up to $20 \%$ (He et al., 2000). The standard temperature and light level conditions are better provided for in a controlled greenhouse environment, which necessitates using saplings.

MEGAN describes the emission of BVOCs in terms of temperature, PAR, leaf area index, leaf age, soil moisture and suppression via ambient $\mathrm{CO}_{2}$ concentrations. Whilst the MEGAN parameterisations are fitted from a wide range of ecosystem responses to environmental conditions, there are spatial and temporal exceptions to these standards, which are comprehensively reviewed by Niinemets et al. (2010). Many studies have investigated impacts of climate change on isoprene by changing the inputs to MEGAN, such as ambient temperatures and $\mathrm{CO}_{2}$ concentrations (e.g. Bauwens et al., 2018), and have also investigated how land use might change the geographical extent of plant functional types (PFTs) (e.g. Arneth et al., 2011) without changing the MEGAN parameterisations themselves. Here we report new controlled isoprene response measurements from four eucalypt tree species, which show different temperature responses than assumed by MEGAN. We also use the controlled experimental conditions to impose a projected 2050 climate to investigate whether eucalypts growing in a warmer climate show a different temperature sensitivity of isoprene emissions than eucalypts growing in the current climate. Accounting for cli- mate warming impacts on isoprene emission capacity provides a lens to study how air quality in Australia could be impacted in the future. Using a regional chemical transport model allows us to alter the dynamics of MEGAN to suit these new temperature responses for Australia.

This study aims to (i) determine the temperature response of isoprene in four Eucalyptus species grown under two treatments, representing current average summertime temperatures and a 2050 climate, and (ii) use these measurements to determine the impacts of isoprene in a future climate on predicted levels of $\mathrm{O}_{3}$ and SOA.

\section{Methods}

\subsection{The MEGAN default temperature response}

Guenther et al. (2012) define the emission of BVOCs in terms of activity factors representing the environmental conditions described above. Here we are interested in studying the temperature response of isoprene, $\gamma T$ (unitless):

$$
\gamma T=E_{\mathrm{opt}} \times\left[\frac{C_{T 2} \times \exp \left(C_{T 1} \times x\right)}{\left(C_{T 2}-C_{T 1} \times\left(1-\exp \left(C_{T 2} \times x\right)\right)\right)}\right],
$$

where $E_{\mathrm{opt}}$ is the optimum emission point, and $C_{T 1}$ $\left(95 \mathrm{~kJ} \mathrm{~mol}^{-1}\right)$ and $C_{T 2}\left(230 \mathrm{~kJ} \mathrm{~mol}^{-1}\right)$ are coefficients that fit the response to a range of ecosystems.

$$
x=\left[\frac{\left(1 / T_{\mathrm{opt}}\right)-(1 / T)}{0.00831}\right],
$$

where $T$ is the temperature of the leaf $(\mathrm{K})$ and 0.00831 is the gas constant $\left(\mathrm{kJ} \mathrm{K}^{-1} \mathrm{~mol}^{-1}\right)$. The optimum temperature for emission throughout MEGAN, $T_{\mathrm{opt}}$, is calculated below.

$$
\begin{aligned}
T_{\mathrm{opt}} & =T_{\mathrm{max}}+\left(0.6 \times\left(T_{240}-T_{\mathrm{S}}\right)\right) \\
E_{\mathrm{opt}} & =C_{\mathrm{eo}} \times \exp \left(0.05 \times\left(T_{24}-T_{\mathrm{S}}\right)\right) \\
& \times \exp \left(0.05 \times\left(T_{240}-T_{\mathrm{S}}\right)\right),
\end{aligned}
$$

where $T_{\max }$ is $313 \mathrm{~K}, T_{\mathrm{S}}$ is the standard leaf temperature $(297 \mathrm{~K})$, and $T_{24}$ and $T_{240}$ are the average leaf temperatures of the previous 24 and $240 \mathrm{~h}$, respectively. $C_{\mathrm{eo}}$ is an empirical coefficient of 2 for isoprene.

\subsection{Experimental conditions}

Four eucalypt species were chosen based on their prevalence in Australia and in particular New South Wales (Table 1). E. camaldulensis and E. tereticornis have a wide geographical representation within Australia, with a latitudinal native growing range of 9-38 $\mathrm{S}$ (Atlas of Living Australia, 2019) (Supplement Fig. S1). E. camaldulensis is the most widely naturally distributed species of all eucalypts in Australia (Atlas of Living Australia, 2019). The native climatic distribution range of $E$. botryoides and $E$. smithii is restricted to the 
Table 1. Geographic range size of each Eucalyptus species in Australia and the isoprene emission rate based on dry leaf weight.

\begin{tabular}{|c|c|c|c|c|c|}
\hline Tree & Common name & Area $\left(\mathrm{km}^{2}\right)^{\mathrm{a}}$ & $\%$ weight & Emission category & Average emission $\left(\mu \mathrm{gg}^{-1} \mathrm{~h}^{-1}\right)$ \\
\hline E. camaldulensis & River red gum & 6040600 & 86.32 & high & $16.6^{\mathrm{b}} \quad 28.0^{\mathrm{c}} \quad 32.5^{\mathrm{d}}$ \\
\hline E. tereticornis & Forest red gum & 792575 & 11.32 & high & $32.7^{\mathrm{e}} \quad 38.2^{\mathrm{f}}$ \\
\hline E. smithii & Blackbutt peppermint & 95750 & 1.37 & unknown & - \\
\hline E. botryoides & Bangalay & 74175 & 1.06 & moderate & $5.3^{\mathrm{b}}$ \\
\hline
\end{tabular}

${ }^{\mathrm{a}}$ Species area in 2014 (from González-Orozco et al., 2016). ${ }^{\mathrm{b}}$ He et al. (2000). ${ }^{\mathrm{c}}$ Karkik and Winer (2001). ${ }^{\mathrm{d}}$ Benjamin et al. (1996). ${ }^{\mathrm{e}}$ Nelson et al. (2000). ${ }^{\mathrm{f}}$ Jiang et al. (2020), from trees growing in ambient $\mathrm{CO}_{2}$ concentrations.

south-east coastal regions. All four species are forecast to exist in future, but only E. camaldulensis is predicted to expand its growing area by 2085 (González-Orozco et al., 2016).

Plant species can be classified as low (less than $1 \mu \mathrm{gg}^{-1} \mathrm{~h}^{-1}$ ), moderate $\left(1-10 \mu \mathrm{gg}^{-1} \mathrm{~h}^{-1}\right.$ ) or high (greater than $10 \mu \mathrm{gg}^{-1} \mathrm{~h}^{-1}$ ) isoprene emitters (Benjamin et al., 1996). Of the four eucalypts used in this study, E. camaldulensis and E. tereticornis are high isoprene emitters (Table 1), whilst $E$. botryoides is classed as moderate. The emission category of $E$. smithii is unknown. All tabulated measurements were scaled to the standard conditions from other temperatures and PAR.

Eighty trees (20 of each species) were grown from seed at Hawkesbury Institute for the Environment in Richmond, NSW. After 8 weeks seedlings were transplanted into $6.9 \mathrm{~L}$ pots filled with alluvial soil and split randomly into two treatment groups, each containing 10 seedlings of each species. The first treatment group was grown for $85 \mathrm{~d}$ at an average daily temperature of $291 \mathrm{~K}$ (current climate), and the second treatment group was grown for $85 \mathrm{~d}$ at $294.5 \mathrm{~K}$ (future climate). In this time the seedlings put on vigorous growth and developed into $\sim 1.5 \mathrm{~m}$ tall saplings with plenty of leaves (see Supplement Fig. S2). The future-climate treatment represents temperature conditions in Australia in 2050 assuming RCP8.5, the highest Representative Concentration Pathway (RCP), in which the business-as-usual scenario sees $\mathrm{CO}_{2}$ reach 940 ppm by 2100 (van Vuuren et al., 2011). The treatments maintained the diurnal variation of the ambient temperature at $9 \mathrm{~K}$. Further details on the growth conditions of these eucalypts are described in Aspinwall et al. (2019) prior to their study of how eucalypts respond to heatwave stress.

We will use our new experimental data to revise the LEF maps for Australia, weighting the results according to the summed area of the four species (Table 1).

\subsection{Temperature response measurements}

Leaf gas exchange measurements were made continuously with an LI-6400XT portable photosynthesis system (LICOR, Inc., Lincoln, NE, USA) connected to a Walz 3010GWK1 leaf cuvette (maximum leaf surface area of $140 \mathrm{~cm}^{2}$; Heinz Walz GmbH, Effeltrich, Germany). The Walz cuvette was controlled via a PC using Walz software (GFS-Win v. $3.47 \mathrm{~g}$ ). $\mathrm{CO}_{2}$ concentrations were set to $400 \mathrm{ppmv}$, and the flow rate through the cuvette was set to $700 \mu \mathrm{mols}^{-1}$. Light was provided using LumiGrow Pro 325 LED growth lamps (LumiGrow, Novato, CA, USA) positioned above the cuvette to provide $1000 \mu \mathrm{mol} \mathrm{m}^{-2} \mathrm{~s}^{-1}$ PAR as measured by the LI6400XT cuvette's light sensor. Leaf temperature was controlled using the Walz cuvette and was programmed to increase leaf temperature in $5 \mathrm{~K}$ steps from 293 to $328 \mathrm{~K}$ in $7 \mathrm{~min}$ intervals to accommodate adjustment to new steadystate values of photosynthesis at each temperature. This time corresponds to the duration of intermediate-length sunflecks in plant canopies (Pearcy, 1990) and also results in a common, standardised heat dose for all the leaves (Niinemets and Sun, 2015). Basal emission rates are taken as the emission rate measured at $1000 \mu \mathrm{mol} \mathrm{m}^{-2} \mathrm{~s}^{-1} \mathrm{PAR}$ and $303 \mathrm{~K}$.

After the gas exchange measurements, leaves were detached and their area measured using an LI-3100C leaf area meter (LI-COR, Inc.). Leaves were oven-dried at $105^{\circ} \mathrm{C}$ for $72 \mathrm{~h}$, after which their dry weight was recorded.

Mixing ratios of isoprene by volume were determined using a high-resolution proton-transfer-reaction mass spectrometer (PTR-MS, Ionicon GmbH, Innsbruck, Austria). The operating parameters of the PTR-MS were held constant during measurements except for the secondary electron multiplier voltage, which was optimised before every calibration. The drift tube pressure, temperature and voltage were $2.2 \mathrm{hPa}, 50^{\circ} \mathrm{C}$ and $600 \mathrm{~V}$, respectively. The parameter $E / N$ was $\sim 125 \mathrm{Td}\left(1.25 \times 10^{-15} \mathrm{~V} \mathrm{~cm}^{2}\right)$ and the reaction time was $\sim 100 \mu \mathrm{s}$. The count rate of $\mathrm{H}_{3} \mathrm{O}^{+} \cdot \mathrm{H}_{2} \mathrm{O}$ ions was $1 \%$ $2 \%$ of the count rate of $\mathrm{H}_{3} \mathrm{O}^{+}$ions, which was 5.0-5.5 $\times$ $10^{6} \mathrm{~s}^{-1}$. Normalised sensitivities and isoprene volume mixing ratios were calculated through calibrations as described by Taipale et al. (2008) using 5 ppmv isoprene (Apel-Riemer Environmental Inc., Broomfield, CO, USA) diluted in highpurity nitrogen (BOC Ltd, Sydney, NSW, Australia). Protonated isoprene was detected by the PTR-MS as its molecular mass plus 1 (i.e. $M+\mathrm{H}+1=69$ ). The duty cycle for each measurement period was $5 \mathrm{~s}$.

Isoprene-temperature response measurements were replicated on five or six saplings of each species in each temperature treatment group (Supplement Fig. S3). The Solver program (generalised reduced gradient non-linear method, default settings; Microsoft Excel for Office 365; Microsoft Corporation, Redmond, WA, USA) was used to estimate four 


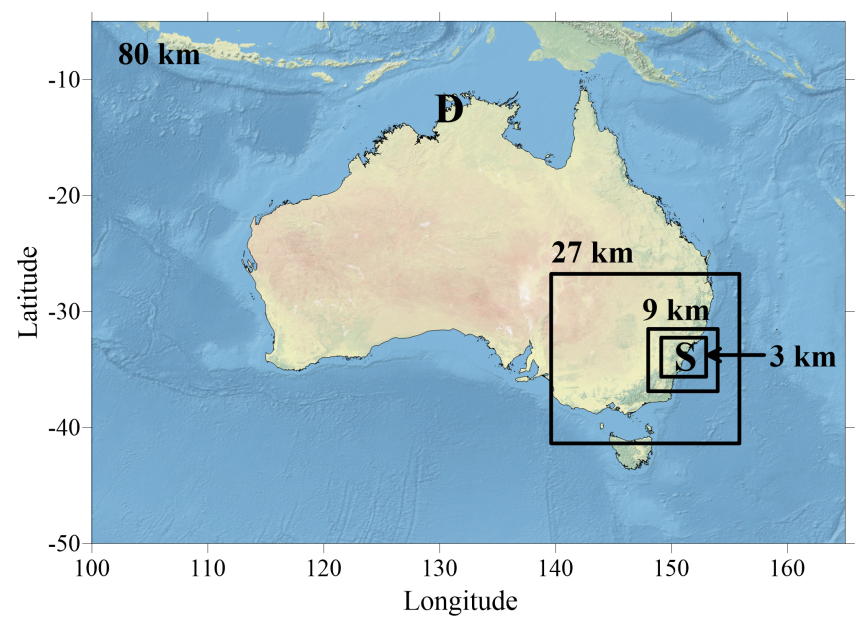

Figure 1. Map to show nests of model domains from $80 \mathrm{~km}$ Australia-wide to $3 \mathrm{~km}$ inner Sydney domain. "S" and "D" mark the locations of Sydney and Darwin, respectively.

MEGAN coefficients, $C_{T 1}, C_{T 2}, T_{\max }$ and $C_{\mathrm{eo}}$, to minimise the difference between the result of Eq. (1) and the measured temperature responses for each tree species and growth temperature treatment. The basal emission rates for each species $\left(\mu \mathrm{g} \mathrm{g}^{-1} \mathrm{~h}^{-1}\right)$ were normalised to the average basal emission factor for that species and its growth temperature treatment. Normalising these data scales the actual emission rates and ensures they have a common basal emission factor of unity.

\subsection{Observations of isoprene mixing ratios}

Few measurements of ambient isoprene exist in Australia. Hourly observations made by proton-transfer-reaction mass spectrometry are available for three summertime urban field campaigns near Sydney (Fig. 1). These observations will be used to evaluate model predictions using our temperature response functions of isoprene emission. Isoprene observations are available from Bringelly for January and February of 2007, from SPS1 in Westmead for February and March of 2011 (Keywood et al., 2019), and from MUMBA in Wollongong for January and February of 2013 (PatonWalsh et al., 2017, 2018). Maximum (and average) measured temperatures were $308.9 \mathrm{~K}(295.9 \mathrm{~K})$ for Bringelly, $310.0 \mathrm{~K}$ (295.6 K) for SPS1 and 317.2 K (295.3 K) for MUMBA. Climate projections for Australia forecast increases in average temperatures with an accompanying increase in the frequency of extreme heatwave days (Bureau of Meteorology and CSIRO, 2018).

\subsection{The CSIRO Chemical Transport Model}

The CSIRO Chemical Transport Model (C-CTM) is a modelling framework designed to predict the atmospheric concentrations of gases and aerosols due to emissions, transport, chemical production and loss, and deposition. In ad- dition to BVOCs, the framework has successfully predicted pollen (Emmerson et al., 2019b), health effects from shipping (Broome et al., 2016) and air quality (Chambers et al., 2019). The C-CTM is driven by meteorology from the Conformal Cubic Atmospheric Model (CCAM; McGregor and Dix (2008)), taking boundary conditions from ERA-Interim. Four nested domains are used at spatial resolutions of 80 , 27, 9 and $3 \mathrm{~km}$ to downscale the atmospheric constituents over topography that increases with complexity at higher resolutions. The inner $3 \mathrm{~km}$ domain contains $114 \times 110$ grid cells to encompass Sydney, Wollongong and the surrounding forested regions (Fig. 1).

The model chemistry scheme is MOZART-T1 (Emmons et al., 2020), incorporating the latest research on isoprene oxidation pathways via additional radical production under low- $\mathrm{NO}_{x}$ conditions. The aerosol framework is a two-bin sectional scheme, processing organic species by the volatility basis set (Shrivastava et al., 2008) and processing inorganic species via ISORROPIA_II (Fountoukis and Nenes, 2007). The high- and low- $\mathrm{NO}_{x}$ aerosol mass yields for the organic species, including isoprene, are provided by Tsimpidi et al. (2010).

Australia-wide anthropogenic emissions come from an inventory based on human population density on a $10 \mathrm{~km} \times$ $10 \mathrm{~km}$ grid resolution (updated from Physick et al., 2002). Anthropogenic emissions for Sydney in the $3 \mathrm{~km}$ domain are based on the most recent NSW inventory for the year 2008 (EPA NSW, 2012). The full-canopy-environment version of MEGAN, version 2.1 (Guenther et al., 2012), was built into the C-CTM to calculate the biogenic emissions (Emmerson et al., 2016). Isoprene emissions, $R$, in a given grid cell, $x y$, are predicted using LEF maps in combination with the land fraction, $\chi$, occupied by 16 PFTs, $j$, using

$$
R=\mathrm{LEF}_{x, y} \sum_{j=1}^{\mathrm{nPFT}}\left(\gamma_{x, y} \times \chi_{j}\right),
$$

where $\gamma$ represents the sum of all activity factors for light, temperature, soil moisture, leaf area index and leaf age. The $\gamma$ for soil moisture is applied using data provided by the SoilLitter-Iso model (SLI), as recommended by Emmerson et al. (2019a). Monthly leaf area index data come from MODIS MCD15A2 version 4.

A PFT map based on the ESA CCI Land Cover distribution for the year 2010 (ESA, 2016) was created. The ESA land cover data were used in conjunction with the MODIS 44B (Vegetation Continuous Fields) product level 5.1 for the year 2012 to provide the percentage of tree, grass and shrub cover. Details on how these land cover data were aggregated or split into the 16 PFTs required by MEGAN2.1 are provided in the Supplement. Eucalypts fall under the broadleaf evergreen temperate tree category. 


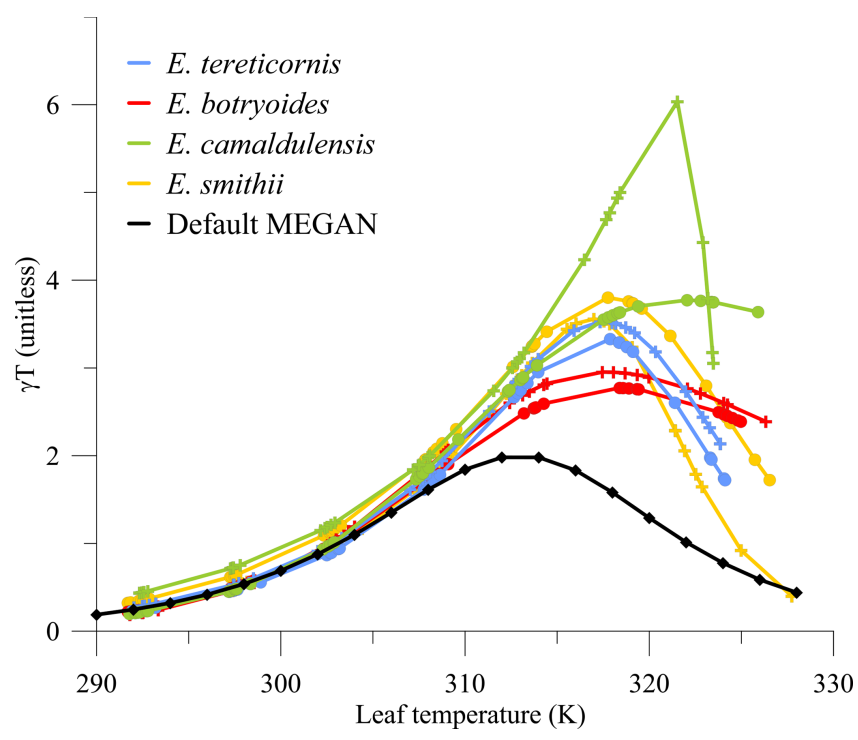

Figure 2. Comparison of $\gamma T$ with leaf temperature calculated using default values in MEGAN to results from four eucalypt tree species under current-climate (filled circles) and future-climate $(+$ sign) growth conditions.

\section{Results and discussion}

\subsection{Temperature response results}

The fitted temperature responses for each eucalypt tree species under both current- and future-climate growth conditions are stronger and shifted to higher leaf temperatures than the MEGAN2.1 default response (Fig. 2). The peaks in current-climate $\gamma T$ are $40 \%-90 \%$ higher than the default MEGAN, whilst the peaks in future-climate $\gamma T$ are $45 \%-200 \%$ higher. The position of the peaks is also shifted towards higher temperature optimums by approximately 4 $9 \mathrm{~K}$. For the current-climate growth treatment results, running MEGAN with default settings would underestimate $\gamma T$ and subsequently the isoprene emission at leaf temperatures greater than $303 \mathrm{~K}$. MEGAN assumes that at growth temperatures lower than the standard conditions, the amplitude of the temperature response $\left(E_{\mathrm{opt}}\right)$ is lowered, and the peak of that response is shifted to a lower temperature $\left(T_{\mathrm{opt}}\right)$. These new data show that this is not necessarily true for all species studied at each growth temperature. Our measurements also indicate that eucalypts have evolved to cope with the high Australian temperatures and can continue to protect themselves against heat damage via isoprene emission until $\sim 320 \mathrm{~K}$. Tree species with wide geographical coverage such as E. camaldulensis may also be better adapted to surviving climate change (González-Orozco et al., 2016).

Each tree in each temperature treatment group produces a similar response (number of trees and their temperatures at maximum $\gamma T$ given in Table 2). For trees grown in the current climate, the temperature optimum in $\gamma T$ is $317-318 \mathrm{~K}$ for E. tereticornis and E. smithii, decreasing at higher leaf temperatures. Both E. camaldulensis and E. botryoides persist at high $\gamma T$ until $328 \mathrm{~K}$, when measurements stopped. For trees grown under future-climate conditions, the $\gamma T$ peak is also $\sim 317 \mathrm{~K}$, and there is a different response of E. camaldulensis and E. botryoides compared to the other species. $\gamma T$ in E. camaldulensis increases steeply with increasing leaf temperature until $321.5 \mathrm{~K}$, thereafter decreasing sharply. This response is common amongst the five E. camaldulensis in the future-climate treatment, although there is scatter around this fitted response. The $E$. camaldulensis result will dominate the weighted variables used in the modelling because of its larger geographic distribution (Table 1). We discuss the impact of this sharp downturn in $\gamma T$ at high temperatures in Sect. 3.3.

\subsection{Isoprene emission rates}

The basal isoprene emission rates (BERs; $\mu \mathrm{gg}^{-1} \mathrm{~h}^{-1}$ ) were measured at the standard $303 \mathrm{~K}$ and $1000 \mu \mathrm{mol} \mathrm{m}^{-2} \mathrm{~s}^{-1}$ PAR (Table 2). As the current-climate growth treatment represents present-day climatic conditions, we only compare these with measurements made previously on the same species. The E. tereticornis BER measurements are lower than those made by Nelson et al. (2000) and Jiang et al. (2020); however our E. camaldulensis BER measurements are around $10 \mu \mathrm{gg}^{-1} \mathrm{~h}^{-1}$ higher than those listed by Benjamin et al. (1996), and our E. botryoides BER measurements are $37 \mathrm{\mu g} \mathrm{g}^{-1} \mathrm{~h}^{-1}$ higher than those measured by He et al. (2000). He et al. (2000) used a mixture of young and mature leaves in their experiments, which could be one explanation for the difference in emission rates as young leaves are expected to be higher emitters than older leaves in Eucalyptus species (Street et al., 1997). However, as the growth conditions (particularly light and temperature) and measurement protocols in this study and $\mathrm{He}$ et al. (2000) were different (we directly measured BER with a leaf cuvette at $303 \mathrm{~K}$ and $1000 \mu \mathrm{mol} \mathrm{m}^{-2} \mathrm{~s}^{-1}$ PAR, while He et al., 2000, used a dynamic chamber and scaled emissions to $303 \mathrm{~K}$ and $1000 \mu \mathrm{mol} \mathrm{m}^{-2} \mathrm{~s}^{-1}$ PAR using algorithms from Guenther et al., 1993), it is difficult to undertake a direct comparison. However, our measurements put the four eucalypt species into the high-emission category.

To create new isoprene emission factor maps suitable for the modelling, we convert the BERs into landscape emission factors $\left(\mathrm{LEF}_{\text {isop }}\right)$. The average $\mathrm{BER}$ for each growth treatment is weighted according to its respective geographical area in Table 1. BERs are then converted into LEFs using the leaf mass per unit area (LMA) in grams per square metre and scaled with the leaf area index (LAI) in square metres per square metre, similar to Emmerson et al. (2018). The isoprene emission factor for trees in each temperature treatment is given by tree_EF isop: $_{\text {: }}$

tree_EF $\mathrm{EF}_{\text {isop }}=\mathrm{BER} \times \mathrm{LAI} \times \mathrm{LMA}$. 
Table 2. Average isoprene basal emission rates (BER), leaf mass per unit area (LMA) and temperature at maximum $\gamma T$ from each pool of trees under the current- and future-climate growth conditions. Values in brackets are standard deviations. Data in the right-hand column are derived from model fits.

\begin{tabular}{llrrrr}
\hline Treatment & Species & No. of trees & BER, $\mu \mathrm{gg}^{-1} \mathrm{~h}^{-1}$ & LMA, g m $^{-2}$ & Temp at max $\gamma T, \mathrm{~K}$ \\
\hline Current climate & E. tereticornis & 6 & $29.14(13.91)$ & $61.53(5.42)$ & 317.8 \\
& E. smithii & 6 & $41.21(17.31)$ & $54.93(13.71)$ & 317.8 \\
& E. botryoides & 6 & $42.46(23.64)$ & $72.51(15.25)$ & 318.4 \\
& E. camaldulensis & 6 & $42.87(22.87)$ & $72.79(6.14)$ & 322.1 \\
\hline Future climate & E. tereticornis & 6 & $41.57(28.08)$ & $64.05(9.58)$ & 317.3 \\
& E. botryoides & 5 & $55.18(27.27)$ & $77.96(12.55)$ & 317.5 \\
& E. smithii & 6 & $61.61(20.01)$ & $58.08(5.10)$ & 317.0 \\
& E. camaldulensis & 5 & $66.95(22.44)$ & $73.18(4.64)$ & 321.5 \\
\hline
\end{tabular}

In the C-CTM, northern Australian vegetation is represented by broadleaf shrubs $(30 \%-40 \%)$ and $\mathrm{C}_{4}$ grasses $(50 \%$ to $80 \%$ in some locations). If the isoprene emission factor maps are only based on the new eucalypt BERs, these are unlikely to be representative of shrubs and grasses. Here we ensure the non-tree fraction of grid cells in Australia is not impacted by these changes using the tree fraction (treefrac) from the ESA product.

$$
\begin{aligned}
& \mathrm{LEF}_{\text {isop }}=\left(\text { tree_EF } \mathrm{EF}_{\text {isop }} \times \text { treefrac }\right) \\
& \quad+\left(\text { orig_EF } \mathrm{EF}_{\text {isop }} \times(1-\text { treefrac })\right)
\end{aligned}
$$

This leaves the fraction of original isoprene LEFs (orig_EF $F_{\text {isop }}$ ) untouched for grass and shrub PFTs.

\subsection{Impacts of changing $C_{T 1}, C_{T 2}, T_{\max }$ and $C_{\mathrm{eo}}$}

Table 3 shows the results of fitting $C_{\mathrm{T} 1}, C_{\mathrm{T} 2}, T_{\max }$ and $C_{\mathrm{eo}}$ compared to the default MEGAN values. These new fitted data are for the four tree species in the experiment, weighted according to their coverage in Table 1 . The new average LEFs from our four eucalypt species are $31 \%-48 \%$ lower than the default average MEGAN LEF we use in the base run for the $3 \mathrm{~km}$ Sydney domain. Previous modelling showed that a $40 \%$ reduction in isoprene was needed to better match the observations from our three field campaigns (Emmerson et al., 2019a).

The value fitted for $C_{T 2}$ is very high $\left(1158.36 \mathrm{~kJ} \mathrm{~mol}^{-1}\right)$ in the future-climate treatment compared with the currentclimate treatment $\left(167.11 \mathrm{~kJ} \mathrm{~mol}^{-1}\right)$ and default MEGAN $\left(230 \mathrm{~kJ} \mathrm{~mol}^{-1}\right)$ due to the E. camaldulensis measurements in Fig. 2. To assess whether $C_{T 2}$ should be re-fitted we examine the impacts of changing each of these variables one at a time using a MEGAN box model designed in Jiang et al. (2020). As the impacts of the new measurements are strongest at higher temperatures, we assume conditions from the hottest day in the MUMBA campaign (18 January 2013). The MEGAN box model runs for $24 \mathrm{~h}$, and the results are given as percentage changes to the maximum isoprene emission in Table 3. For the given fitted values on this day, the
$C_{T 1}$ variable has the least and $C_{\mathrm{eo}}$ has the most impact on isoprene emissions. The high $C_{T 2}$ value in the future-climate treatment will not be refitted as the incurred $19 \%$ decrease in isoprene is small compared with the $282 \%$ increase caused by $C_{\mathrm{eo}}$. Individually, $C_{\mathrm{eo}}$ has the greatest impact on isoprene emissions but is regulated by increasing $T_{\max }$ when used in tandem with other variables. However, when all variables operate together the overall impact is an $\sim 80 \%$ increase in isoprene emissions for both current- and future-climate growth conditions. Inclusion of the average LEF reduces the maximum isoprene emission by $7 \%$ in the current-climate treatment conditions and increases by $23 \%$ in the future-climate treatment conditions on the default.

\subsection{Model experiment set-up}

Seven model experiments are defined (Table 4) and are run for the periods of the field campaigns described in Sect. 2.4. We model the impacts of using the new current- and futureclimate treatment temperature response variables separately from the impacts of the new LEFs on atmospheric isoprene mixing ratios. For experiments 1 to 5 , we use the same hourly meteorology, present-day tree distribution maps and LAI datasets to drive the C-CTM. This allows us to separate the temperature effect in isoprene emissions from other influences which may change in a future climate. The intention is to investigate changes in isoprene emissions resulting from the temperature response results, not to combine these with future land use changes and how the hourly meteorology will be impacted by climate change. However, in experiment 6 we use a simple delta-scaling approach to address how a future climate may impact the driving input temperatures to MEGAN.

We take the average change ( $\delta 2050)$ in projected summertime surface temperatures for Australia under the RCP8.5 scenario from eight models in the Coupled Model Intercomparison Project 5 (CMIP5) (for details see Supplement). Delta-scaling adds $\sim 2 \mathrm{~K}$ to the surface temperatures near Sydney. We only scale the surface temperature; thus experiment 6 is not a 2050 representation of the whole atmosphere. 
Table 3. Changes to MEGAN variables based on fitted data from current- and future-climate growth experiments. Percentages in brackets indicate change in maximum daily isoprene emissions due to change in variable.

\begin{tabular}{lrrr}
\hline & MEGAN2.1 & $\begin{array}{r}\text { Current-climate } \\
\text { growth treatment }\end{array}$ & $\begin{array}{r}\text { Future-climate } \\
\text { growth treatment }\end{array}$ \\
\hline Average LEF $\left(\mu \mathrm{g} \mathrm{g}^{-1} \mathrm{~h}^{-1}\right)$ & $9491^{*}$ & $4919(-48 \%)$ & $6585(-31 \%)$ \\
$C_{T 1}\left(\mathrm{~kJ} \mathrm{~mol}^{-1}\right)$ & 95 & $110.55(-1 \%)$ & $75.04(+1 \%)$ \\
$C_{T 2}\left(\mathrm{~kJ} \mathrm{~mol}^{-1}\right)$ & 230 & $167.11(+5 \%)$ & $1158.36(-19 \%)$ \\
$T_{\max }(\mathrm{K})$ & 313 & $325(-55 \%)$ & $323(-46 \%)$ \\
$C_{\text {eo }}$ & 2 & $6.77(+238 \%)$ & $7.69(+282 \%)$ \\
All variables without LEF & & $+81 \%$ & $+76 \%$ \\
All variables + LEF & & $-7 \%$ & $+23 \%$ \\
\hline
\end{tabular}

* Value of average LEF from the inner $3 \mathrm{~km}$ domain.

Table 4. Description of each model experiment. CC: current climate; FC: future climate.

\begin{tabular}{llllll}
\hline Experiment & Name & $\begin{array}{l}\text { Emission } \\
\text { factors }\end{array}$ & $\begin{array}{l}\text { Temperature } \\
\text { response }\end{array}$ & $\begin{array}{l}\text { Meteorology used to } \\
\text { drive MEGAN }\end{array}$ & $\gamma C$ \\
\hline 1 & Base & default & default & current & $\mathrm{x}$ \\
2 & CC_ $\gamma T$ & default & fitted CC & current & $\mathrm{x}$ \\
3 & CC_ $\gamma T+\mathrm{LEF}$ & CC LEF & fitted CC & current & $\mathrm{x}$ \\
4 & FC_ $\gamma T$ & default & fitted FC & current & $\mathrm{x}$ \\
5 & FC_ $\gamma T+\mathrm{LEF}$ & FC LEF & fitted FC & current & $\mathrm{x}$ \\
6 & Climate2050 & FC LEF & fitted FC & current $+\delta 2050$ & $\mathrm{x}$ \\
7 & Climate2050_ $\gamma C$ & FC LEF & fitted FC & current $+\delta 2050$ & $\checkmark$ \\
\hline
\end{tabular}

This restricts the use of the delta-scaled temperatures as a MEGAN input and not the temperature used for chemical reactions as mass balance difficulties would occur by not also delta-scaling the pressure and air density through the height of the atmosphere. We estimate that the reaction rate of isoprene with $\mathrm{OH}$ (calculated as $2.54 \times 10^{-11} \exp (410 / T)$ in MOZART-T1) would decrease by $1.7 \%$ with the $3.5 \mathrm{~K}$ temperature rise between our current- and future-climate growth treatments.

The climate2050 run does not include the associated increases in $\mathrm{CO}_{2}$ mixing ratios, to be consistent with our measurements that were also not conducted in a higher- $\mathrm{CO}_{2}$ atmosphere. A seventh simulation assumes a $550 \mathrm{ppm} \mathrm{CO}_{2}$ atmosphere on top of the delta-scaled surface temperatures, employing the Heald et al. (2009) method for calculating short- and long-term $\mathrm{CO}_{2}$ activity factors, $\gamma C$. Fixing the atmospheric $\mathrm{CO}_{2}$ to $550 \mathrm{ppm}$ reduces the isoprene emissions by $5 \%$ in the short term and $13 \%$ in the long term.

If the leaf temperature is varied within Eqs. (1)-(4) and $\gamma T$ is multiplied by the LEF, the impacts of experiments 15 on isoprene emission start at about $283 \mathrm{~K}$ (Fig. 3). Experiment 6 follows the FC_ $\gamma T+$ LEF profile. Here, the new current- and future-climate LEFs are normalised by the default MEGAN LEF. The default MEGAN profile has a peak isoprene emission at $311 \mathrm{~K}$. The $\mathrm{CC}_{-} \gamma T$ and $\mathrm{FC}_{-} \gamma T$ experiments cause the isoprene emission peak to shift to $324 \mathrm{~K}$, with 3 times the default emission value. The sharp downturn in isoprene emission in the FC_ $\gamma T$ and FC_ $\gamma T+$ LEF experiments after $324 \mathrm{~K}$ is due to the high $\gamma T$ of $E$. camaldulensis depicted in Fig. 2. However, these results will not impact the C-CTM runs as no hourly temperature in our three field campaigns exceeds $317 \mathrm{~K}$. Most of the impacts on the CCTM runs will occur in the $288-308 \mathrm{~K}$ range. While there is a very small decrease in the $C_{-} \gamma T$ response compared with the default MEGAN profile at temperatures less than $300 \mathrm{~K}$, overall we expect more isoprene to be emitted in the $\mathrm{CC}_{-} \gamma T$ and $\mathrm{FC}_{-} \gamma T$ experiments than in the default MEGAN profile. While it is intuitive to expect less isoprene to be emitted in the $\mathrm{CC}_{-} \gamma T+\mathrm{LEF}$ and $\mathrm{FC}_{-} \gamma T+\mathrm{LEF}$ experiments than in the base run (from Fig. 3), this may not be the case due to spatial heterogeneity in the new current- and future-climate LEF maps. The LEFs used in Fig. 3 are based on the domain spatial average value; however the LEFs in experiments 3 and 5 are based on the distribution of LAI from Eq. (6), whilst experiments 1, 2 and 4 use the original MEGAN LEF distribution. The results from experiments 3 and 5 certainly show a sustained isoprene decrease below 314 and $311 \mathrm{~K}$, respectively. Distance from source to receptor, transport and dilution will all impact results and are determined by running the C-CTM. 


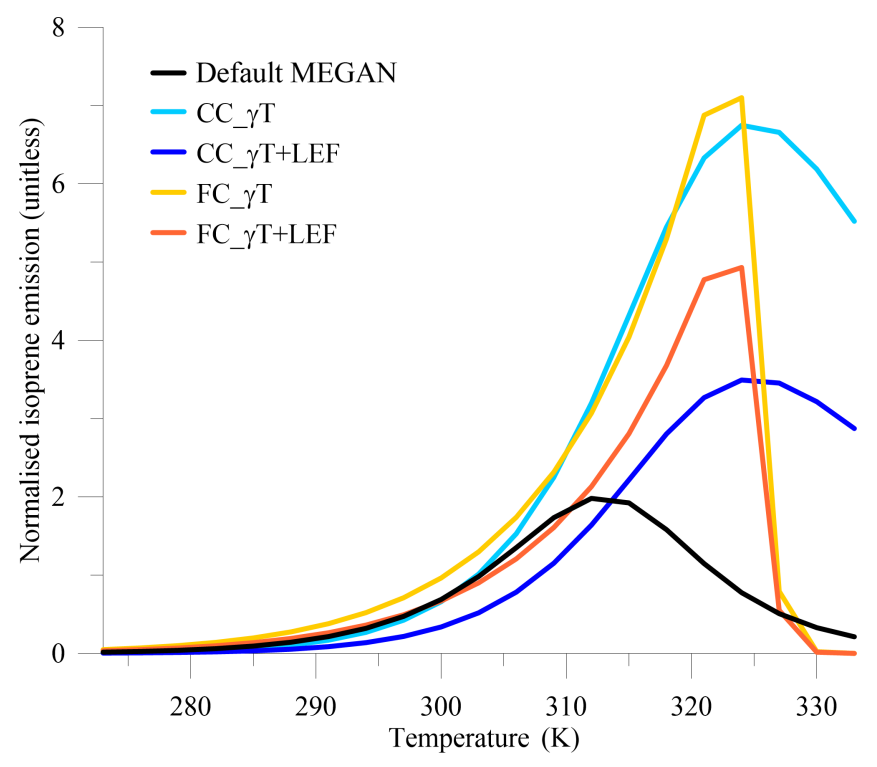

Figure 3. Impacts of new MEGAN variables on normalised isoprene emission rates at increasing ambient temperatures.

\subsection{C-CTM results}

The C-CTM is compiled with changes to MEGAN implemented according to Table 3, run for experiments 1-6 (Table 4), and the isoprene time series is extracted at each field campaign site. The modelled mean diurnal profiles of isoprene are then compared to the mean diurnal observations taken at each field campaign (Fig. 4). Blank samples are taken at least twice a day, incurring frequent regular gaps in observed isoprene. The $\mathrm{CC}_{-} \gamma T$ variables only increase the isoprene mixing ratios when temperatures exceed $303 \mathrm{~K}$ (from Fig. 3). This has changed the shape of the diurnal profiles of each field campaign in different ways, but generally the $\mathrm{CC}_{-} \gamma T$ and $\mathrm{CC}_{-} \gamma T+\mathrm{LEF}$ experiments have increased the diurnal modelled to observed $r^{2}$ when compared with the $r^{2}$ between the base run and observations. The average modelled isoprene in the $\mathrm{CC}_{-} \gamma T+\mathrm{LEF}$ run is within \pm 1 standard deviation of the observations $90 \%-100 \%$ of the time during Bringelly and SPS1 and $33 \%$ of the time during MUMBA, which continues to exhibit high bias (Supplement Fig. S4). In MUMBA, the $\mathrm{CC}_{-} \gamma \mathrm{T}$ increases the isoprene mixing ratios above the base run between 11:00 and 17:00 AEDT in the heat of the day. Very hot temperatures during the day can often be accompanied by strong, gusty winds from the Australian interior. The hottest campaign day during MUMBA, 18 January 2013, was associated with the highest average hourly wind measurement of $8 \mathrm{~m} \mathrm{~s}^{-1}$. Hot and windy conditions would cause lots of sun-flecking within the tree canopy, causing sudden temperature spikes on the leaf surface. Physiologically, the increased production of isoprene during temperature and light spikes helps to maintain photosynthesis (Behnke et al., 2010) during times of mild stresses (Loreto and Fineschi, 2015) above and beyond leaf cooling via transpiration processes (Sharkey et al., 2008). High isoprene emitters can better survive prolonged heatwaves (Yáñez-Serrano et al., 2019), although the Aspinwall et al. (2019) study on our four eucalypt species showed that trees grown under future-climate conditions suffered greater heatwave damage than the same species in current-climate conditions.

During all campaigns the $\mathrm{CC}_{-} \gamma T$ results have decreased the isoprene from the base runs in the morning between 08:00 and 11:00 AEDT because these temperatures are less than $303 \mathrm{~K}$, where the $\gamma T$ values are less than the default MEGAN profile (Fig. 3). The CC_ $\gamma T+\mathrm{LEF}$ experiments represent present-day conditions, with roughly the correct magnitude (MUMBA excepted) of predicted isoprene and best statistical fit compared with the observations. The FC_ $\gamma T+$ LEF experiment has produced more daytime isoprene than the base run contrary to the prediction in Fig. 3 because the distribution of isoprene LEFs near the field campaign sites is different to the default MEGAN LEFs. The climate 2050 experiment adds between $110 \%$ and $170 \%$ more isoprene during the day, or approximately $2 \mathrm{ppb}$. Across the three campaigns, the addition of a higher- $\mathrm{CO}_{2}$ atmosphere reduced the daytime isoprene by $15 \%-26 \%$ of the climate2050 run.

The MUMBA and SPS1 base diurnal profiles show too much isoprene in the model overnight compared to observed mean values, particularly in the period between midnight and 06:00 AEDT. This is because there is more isoprene in the model atmosphere than was quenched by the $\mathrm{OH}$ radical before the $\mathrm{OH}$ production ceased at sundown. The isoprene becomes more concentrated at the surface because of the reduced boundary layer height; the apparent increase between midnight and 03:00 AEDT is not due to night-time isoprene emissions. Conversely a slight rise in the model boundary layer at 04:00 AEDT in SPS1 causes dilution of the atmospheric isoprene. While there are few measurements of isoprene during these predawn periods, it is unlikely that isoprene is present. Only when daytime isoprene is reduced in the $C_{-} \gamma T+$ LEF experiment do we see that the apparent night-time isoprene is decreased.

We investigate the spatial changes to isoprene, $\mathrm{O}_{3}$ and biogenic SOA in an implied future by subtracting results from the CC_ $\gamma T+$ LEF experiment from the climate 2050 experiment during the period of the SPS1 campaign (Fig. 5). These emissions, mixing ratios and aerosol concentrations represent campaign averages from SPS1. We also show the smaller differences found between the $\mathrm{FC}_{-} \gamma T+\mathrm{LEF}$ and CC_ $\gamma T+$ LEF runs. The climate 2050 experiment produces up to $5.2 \mathrm{mg} \mathrm{m}^{-2} \mathrm{~h}^{-1}$ in isoprene emissions to the immediate north of Sydney (Fig. 5d), but there are also increases in the north of Australia (Fig. 5c). The largest changes in isoprene, amounting to $15.8 \mathrm{ppb}$, occur in sparsely inhabited northern Australia (Fig. 5g) and in urbanised pockets to the south and east, where Sydney is located. Urbanisation becomes impor- 

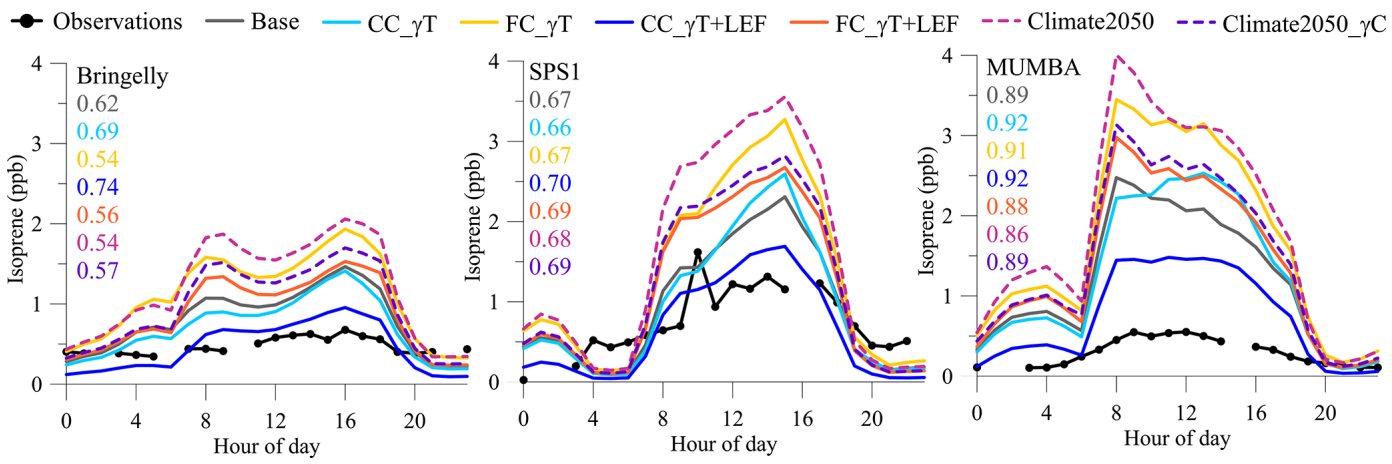

Figure 4. Average diurnal time series in isoprene mixing ratios incurred by the different model experiments at each field campaign site. $r^{2}$ values between modelled and observed isoprene given in the same colours as the legend.

tant when the increased isoprene reacts with $\mathrm{NO}_{x}$ in the atmosphere, causing a peak increase in $\mathrm{O}_{3}$ of 9 ppb near Sydney with the climate2050 differences (Fig. 51). However, the FC_ $\gamma T+$ LEF differences (Fig. 5i) show a 0.5 ppb decrease in $\mathrm{O}_{3}$ in northern Australia via quenching by the additional isoprene. Few inhabitants reside in northern Australia, meaning $\mathrm{O}_{3}$ production via anthropogenic $\mathrm{NO}_{x}$ is minimised. Soil $\mathrm{NO}_{x}$ emissions are low in northern Australia as agricultural practices largely occur in the south-east and south-west of Australia. The $\mathrm{O}_{3}$ deficit is still visible in the very north-east of Australia in the climate2050 difference run (Fig. 5k). The increase in biogenic SOA occurs mainly in the north of Australia, where up to $0.21 \mu \mathrm{g} \mathrm{m}^{-3}$ more aerosol is predicted by the climate 2050 experiment than the CC_ $\gamma T+\mathrm{LEF}$ experiment (Fig. 5o).

The size fraction of most secondary organic aerosol fits within the $\mathrm{PM}_{2.5}$ classification, defined as particulate matter with an aerodynamic diameter less than $2.5 \mu \mathrm{m}$. Australia sets National Environmental Protection Measures (NEPMs) for $\mathrm{PM}_{2.5}$ and $\mathrm{O}_{3}$ to ensure a healthy standard of air quality for the population. The NEPM for $\mathrm{O}_{3}$ is $100 \mathrm{ppb}$ as a $1 \mathrm{~h}$ average and $25 \mu \mathrm{g} \mathrm{m}^{-3}$ as a $24 \mathrm{~h}$ average for $\mathrm{PM}_{2.5}$, with the goal of reducing the $\mathrm{PM}_{2.5}$ limit to $20 \mu \mathrm{g} \mathrm{m}^{-3}$ by 2025 . We examine the increases brought about by climate-induced isoprene in the two cities impacted most by these changes, Sydney and Darwin, in Australia's north (Fig. 6).

The air quality index $(\mathrm{AQI}=\mathrm{NEPM} /$ pollutant concentration $\times 100$ ) in Sydney and Darwin is classed as "very good" (AQI < 33) for both pollutants (years 2009-2014), with an improving trend for $\mathrm{O}_{3}$ but a declining trend for $\mathrm{PM}_{2.5}$ (Keywood et al., 2016). Darwin is a small city, and the biogenic component of $\mathrm{O}_{3}$ changes is less than $2 \mathrm{ppb}$. However peak $\mathrm{O}_{3}$ in Sydney increases by $10-15 \mathrm{ppb}$ as an hourly average in the $\mathrm{FC}_{-} \gamma T+\mathrm{LEF}$ differences but by $12-17 \mathrm{ppb}$ in the climate2050_ $\gamma C$ differences and by as much as $15-21 \mathrm{ppb}$ in the climate2050 differences (Fig. 6a, b). These increases represent $10 \%-21 \%$ of the $\mathrm{O}_{3}$ NEPM and show that by doing nothing (e.g. tree type and coverage or air quality policies do not change) and allowing the temperatures to rise, large cities will likely encounter more NEPM exceedances. The solution is not to remove native trees as they provide social amenity and have cultural significance for indigenous populations. Rather, their emissions must be accommodated via atmospheric $\mathrm{NO}_{x}$ reductions. New urban developments should consider the BVOC emission potential of trees before planting (Paton-Walsh et al., 2019), taking into account that non- or low-emitting trees may not withstand climateinduced heatwaves (Peñuelas and Munné-Bosch, 2005).

The SOA from isoprene is a small fraction of the $\mathrm{PM}_{2.5}$ limit (shown here as $24 \mathrm{~h}$ averages), though of the BVOC aerosol yields, isoprene is not expected to dominate. The aerosol yields from monoterpenes are 10-20 times higher than the isoprene yield, and the monoterpene emission would increase in a warming climate (not investigated here). The climate 2050 differences (and climate2050_ $\gamma C$ ) show days with an increase of $0.42 \mu \mathrm{g} \mathrm{m}^{-3}$ in Sydney and $0.14 \mu \mathrm{g} \mathrm{m}^{-3}$ in Darwin (2\% and $1 \%$ of the $\mathrm{PM}_{2.5} 2025$ NEPM, respectively).

\section{Conclusions}

We have measured the isoprene emission response to controlled increases in temperature from four eucalypt species, two of which have a large geographical growing extent in Australia. The trees were grown in temperatures representing current-climate summertime conditions in Australia and in temperatures representing the projected summertime conditions of $+3.5 \mathrm{~K}$ warming under the business-as-usual RCP8.5 scenario. Climate projections for Australia forecast increases in average temperatures with an accompanying increase in the frequency of extreme heatwave days (Bureau of Meteorology and CSIRO, 2018). This will likely increase the number of days above $303 \mathrm{~K}$.

The current-condition experiments demonstrated a change in the isoprene emission response to temperature as compared with the default parameterisation in MEGAN. This is not a surprise as MEGAN is built to represent a range in ecosystem responses but may go some way to explain 

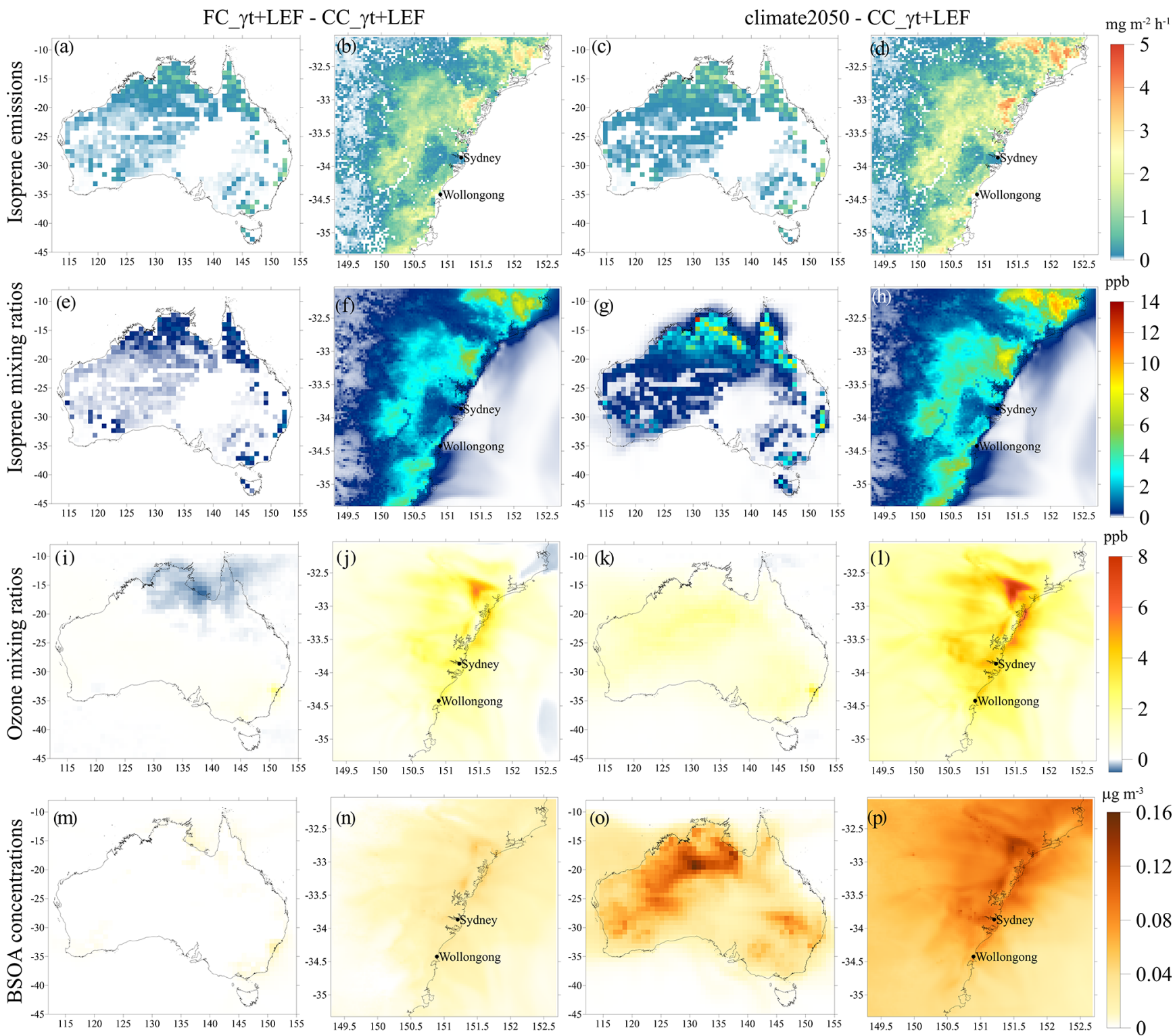

Figure 5. Difference between FC_ $\gamma T+\mathrm{LEF}$ and $\mathrm{CC}_{-} \gamma T+\mathrm{LEF}$ runs $(\mathbf{a}, \mathbf{b}, \mathbf{e}, \mathbf{f}, \mathbf{i}, \mathbf{j}, \mathbf{m}, \mathbf{n})$ during the SPS1 campaign. The difference between the climate2050 runs and CC_ $\gamma T+\mathrm{LEF}$ runs is shown in panels $(\mathbf{c}),(\mathbf{d}),(\mathbf{g}),(\mathbf{h}),(\mathbf{k}),(\mathbf{l}),(\mathbf{o})$ and $(\mathbf{p})$. (a-d) Isoprene emission, (e-h) isoprene mixing ratio, (i-l) ozone mixing ratio, (m-p) biogenic SOA concentration in Australia at $80 \mathrm{~km}$ and Sydney at $3 \mathrm{~km}$ domains.

why difficulties have been encountered when modelling isoprene in Australia previously. Both the current- and futureclimate growth treatment temperature responses shifted the peak in $\gamma T$ by $4-9 \mathrm{~K}$, signifying that these four eucalypt species were observed to continue emitting isoprene until well past the default maximum temperature for emission at $313 \mathrm{~K}$. This suggests that the eucalypts used in this study have evolved to protect themselves against higher temperatures as expected with climate change.

Higher basal emission rates were measured in three of the eucalypt species in our experiment than have been previously measured. However, the conversion of these average weighted emission rates to LEFs for use in the C-CTM resulted in a lower average LEF than is currently being used in the base run. This is due to low biomass measured on our leaves and because the isoprene emission factors from regions described as shrubs or grasslands were not altered. The spatial distribution of the new LEFs was based on the LAI distribution, which differs from the default MEGAN isoprene LEF map.

The model results using the new current-climate growth temperature responses improved the statistical fits of the diurnal profiles compared to the measurements of average isoprene across our three field campaign periods. The overall 


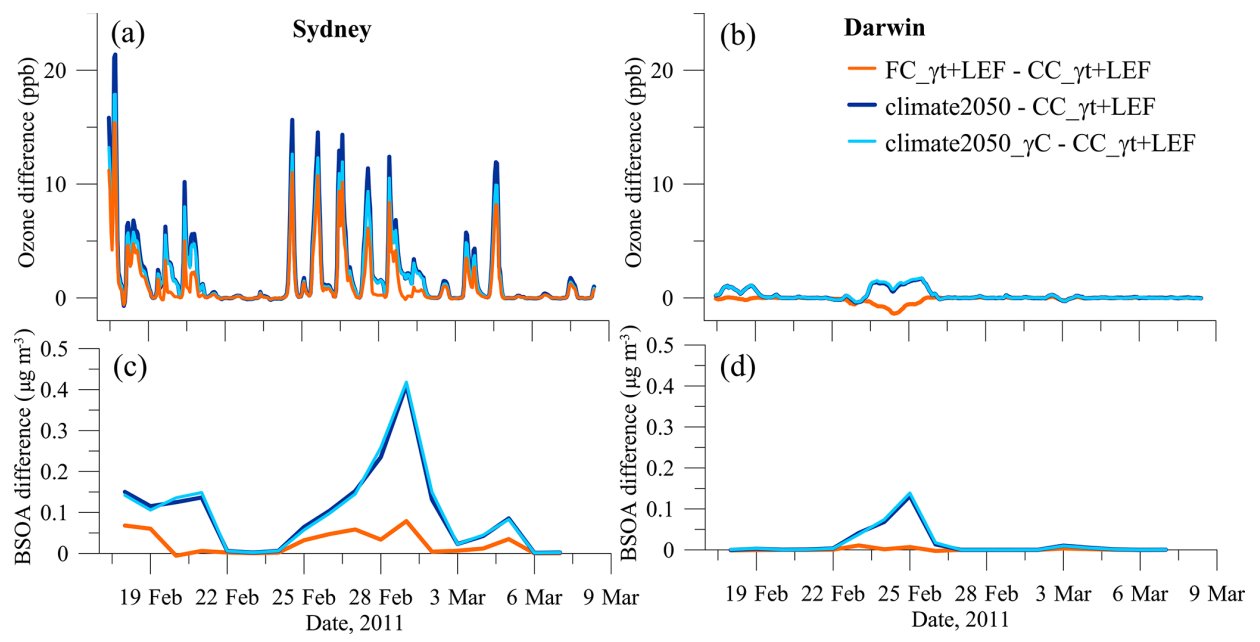

Figure 6. Differences in hourly ozone (a, b) and biogenic secondary organic aerosol (c, d) due to three 2050 experiments at Sydney and Darwin during the SPS1 campaign period.

magnitude of the modelled profile was also brought into better agreement with observations in combination with the new current-climate-growth LEFs. MEGAN2.1 essentially works using a series of variables dependent on vegetation type and biogenic compound emission traits, and the results here suggest that the four MEGAN variables altered in our experiments could also become ecosystem- or location-specific.

Our measurements were conducted on sapling trees, which may exhibit higher isoprene emissions than adult trees when emission rates are expressed based on leaf mass but not when they are based on leaf area (Street et al., 1997). Street et al. (1997) attributed this to younger leaves having a higher specific leaf area than older leaves because eucalypts exhibit heterophylly (the foliage leaves on the same plant are of two distinctly different types). The apparent difference in emission rates between young and old leaves could be a consequence of morphology rather than biochemistry, so we expect the trend between the current- and future-climate-growth emissions to be similar amongst trees of all ages. Our model experiments simulating isoprene emissions in a 2050 climate examined the differences between these runs and the $C_{-} \_\gamma+\mathrm{LEF}$ experiment. Three future experiments were conducted, the first using present-day meteorology, the second using a delta-scaled surface temperature change to projected 2050 summertime temperatures and the third using a $550 \mathrm{ppm}$ atmospheric $\mathrm{CO}_{2}$ on top of the delta-scaled temperatures. The FC_ $\gamma T+\mathrm{LEF}$ experiment showed increases in isoprene emissions in the north of Australia as well as closer to Sydney. These increases led to $\mathrm{O}_{3}$ rising $10-15 \mathrm{ppb}$ close to Sydney as a result of the increased isoprene whilst decreasing in sparsely populated northern Australia through quenching by the additional isoprene. The climate 2050 experiment showed much larger increases in isoprene, $\mathrm{O}_{3}$ and biogenic SOA across Australia, tempered slightly by the addition of increased atmospheric $\mathrm{CO}_{2}$. Delta-scaling the surface tem- peratures was the simplest way of conducting future-climate experiments. Future work should investigate getting a downscaled version of the 2050 atmosphere from the CCAM, which would provide the hourly meteorology throughout the atmosphere that the C-CTM requires.

The future is expected to bring increased temperatures, $\mathrm{CO}_{2}$ and land use changes. Sharkey and Monson (2014) evaluated the isoprene trade-off in each of these scenarios and concluded that the temperature effects would dominate. $\mathrm{O}_{3}$ is a secondary product of isoprene oxidation and is currently maintained at healthy levels in Australia. In order to maintain these levels, air quality policy should investigate methods to reduce anthropogenic $\mathrm{NO}_{x}$ emissions in city regions to accommodate these climate-change-induced increases in BVOC emissions. In addition, tree-planting efforts in new urban developments should also consider the BVOC emission potential of prospective trees.

Data availability. The temperature response measurements reported in this paper are available from https://doi.org/10.25919/5ea918835c3fc (Emmerson et al., 2020) along with modelled time series data used in Figs. 4 and 6. The LAI data product was retrieved from MCD15A2 version 4 from the online Data Pool, courtesy of the NASA Land Processes Distributed Active Archive Center (LP DAAC), USGS/Earth Resources Observation and Science (EROS) Center, Sioux Falls, South Dakota, https://lpdaac.usgs.gov/data_access/data_pool (last access: June 2004; NASA LP DAAC, 2004).

Supplement. The supplement related to this article is available online at: https://doi.org/10.5194/acp-20-6193-2020-supplement. 
Author contributions. KME and MP devised the modelling study and wrote the manuscript. KME conducted the modelling. MP, MJA, SP and MGT conducted the experimental work. MJA, SP and MGT edited the manuscript.

Competing interests. The authors declare that they have no conflict of interest.

Acknowledgements. Kathryn M. Emmerson thanks Christine Wiedinmyer at the University of Colorado Boulder for assistance with the ESA land cover product data and John Clarke at CSIRO for helpful discussions on using the climate projection data.

Review statement. This paper was edited by Janne Rinne and reviewed by two anonymous referees.

\section{References}

Arneth, A., Schurgers, G., Lathiere, J., Duhl, T., Beerling, D. J., Hewitt, C. N., Martin, M., and Guenther, A.: Global terrestrial isoprene emission models: sensitivity to variability in climate and vegetation, Atmos. Chem. Phys., 11, 8037-8052, https://doi.org/10.5194/acp-11-8037-2011, 2011.

Aspinwall, M. J., Pfautsch, S., Tjoelker, M. G., Vårhammar, A., Possell, M., Drake, J. E., Reich, P. B., Tissue, D. T., Atkin, O. K., Rymer, P. D., Dennison, S., and Van Sluyter, S. C.: Range size and growth temperature influence Eucalyptus species responses to an experimental heatwave, Glob. Change Biol., 25, 16651684, https://doi.org/10.1111/gcb.14590, 2019.

Atlas of Living Australia: Eucalyptus camaldulensis, available at: https://bie.ala.org.au/species/https://id.biodiversity.org. au/node/apni/2921040, last access: 6 September 2019.

Bauwens, M., Stavrakou, T., Müller, J.-F., Van Schaeybroeck, B., De Cruz, L., De Troch, R., Giot, O., Hamdi, R., Termonia, P., Laffineur, Q., Amelynck, C., Schoon, N., Heinesch, B., Holst, T., Arneth, A., Ceulemans, R., Sanchez-Lorenzo, A., and Guenther, A.: Recent past (1979-2014) and future (2070-2099) isoprene fluxes over Europe simulated with the MEGAN-MOHYCAN model, Biogeosciences, 15, 3673-3690, https://doi.org/10.5194/bg-15-3673-2018, 2018.

Behnke, K., Loivamäki, M., Zimmer, I., Rennenberg, H., Schnitzler, J.-P., and Louis, S.: Isoprene emission protects photosynthesis in sunfleck exposed Grey poplar, Photosynthesis research, 104, 517, https://doi.org/10.1007/s11120-010-9528-x, 2010.

Benjamin, M. T., Sudol, M., Bloch, L., and Winer, A. M.: Lowemitting urban forests: A taxonomic methodology for assigning isoprene and monoterpene emission rates, Atmos. Environ., 30, 1437-1452, https://doi.org/10.1016/1352-2310(95)00439-4, 1996.

Broome, R. A., Cope, M. E., Goldsworthy, B., Goldsworthy, L., Emmerson, K., Jegasothy, E., and Morgan, G. G.: The mortality effect of ship-related fine particulate matter in the Sydney greater metropolitan region of NSW, Australia, Environ. Int., 87, 85-93, 2016.
Brophy, J. J., House, A. P. N., Boland, D. J., and Lassak, E. V.: Digest of the essential oils of 111 species from northern and eastern Australia, in: Eucalyptus Leaf Oils: Use, Chemistry, Distillation and Marketing, edited by: Boland, D. J., Brophy, J. J., and House, A. P. N., Inkarta Press, Melbourne, 129-155, 1991.

Bureau of Meteorology and CSIRO: State of the Climate 2018, available at: http://www.bom.gov.au/state-of-the-climate/index. shtml (last access: 18 October 2019), 2018.

Chambers, S. D., Guerette, E.-A., Monk, K., Griffiths, A. D., Zhang, Y., Duc, H., Cope, M., Emmerson, K. M., Chang, L. T., Silver, J. D., Utembe, S., Crawford, J., Williams, A. G., and Keywood, M.: Skill-Testing Chemical Transport Models across Contrasting Atmospheric Mixing States Using Radon-222, Atmosphere, 10, 25, https://doi.org/10.3390/atmos10010025 2019.

Department of Agriculture and Water Resources: Australia's State of the Forests Report 2018, available at: https://www.agriculture. gov.au/abares/forestsaustralia/sofr/sofr-2018 (last access: 2 December 2019), 2018.

Emmerson, K. M., Galbally, I. E., Guenther, A. B., Paton-Walsh, C., Guerette, E.-A., Cope, M. E., Keywood, M. D., Lawson, S. J., Molloy, S. B., Dunne, E., Thatcher, M., Karl, T., and Maleknia, S. D.: Current estimates of biogenic emissions from eucalypts uncertain for southeast Australia, Atmos. Chem. Phys., 16, 6997-7011, https://doi.org/10.5194/acp-16-6997-2016, 2016.

Emmerson, K. M., Cope, M. E., Galbally, I. E., Lee, S., and Nelson, P. F.: Isoprene and monoterpene emissions in south-east Australia: comparison of a multi-layer canopy model with MEGAN and with atmospheric observations, Atmos. Chem. Phys., 18, 7539-7556, https://doi.org/10.5194/acp-18-7539-2018, 2018.

Emmerson, K. M., Palmer, P. I., Thatcher, M., Haverd, V., and Guenther, A. B.: Sensitivity of isoprene emissions to drought over south-eastern Australia: Integrating models and satellite observations of soil moisture, Atmos. Environ., 209, 112-124, https://doi.org/10.1016/j.atmosenv.2019.04.038, 2019a.

Emmerson, K. M., Silver, J. D., Newbigin, E., Lampugnani, E. R., Suphioglu, C., Wain, A., and Ebert, E.: Development and evaluation of pollen source methodologies for the Victorian Grass Pollen Emissions Module VGPEM1.0, Geosci. Model Dev., 12, 2195-2214, https://doi.org/10.5194/gmd-12-2195-2019, $2019 \mathrm{~b}$.

Emmerson, K. M., Possell, M, Aspinwall, M. J., Pfautsch, S., and Tjoelker, M. G.: Data associated with "Temperature response measurements from eucalypts give insight into the impact of Australian isoprene emissions on air quality in 2050", v1, CSIRO, Data Collection, https://doi.org/10.25919/5ea918835c3fc, 2020.

Emmons, L. K., Orlando, J. J., Tyndall, G., Schwantes, R. H., Lamarque, J.-F., Marsh, D., Mills, M. J., Tilmes, S., Buchholz, R. R., Gettelman, A., Garcia, R., Simpson, I., Meinardi, S., and Pétron, G.: The Chemistry Mechanism in the Community Earth System Model version 2, J. Adv. Model. Earth Sy., 12, e2019MS001882, https://doi.org/10.1029/2019MS001882, 2020.

EPA NSW: air-emissions-inventory, NSW Environment Protection Authority, available at: https://www.epa.nsw. gov.au/your-environment/air/air-emissions-inventory/ air-emissions-inventory-2008 (last access: 21 May 2020), 2012. 
ESA: CI Land Cover dataset (v 1.6.1), available at: https://www. esa-landcover-cci.org/?q=node/169 (last access: 4 September 2019), 2016.

Evans, R. C., Tingey, D. T., Gumpertz, M. L., and Burns, W. F.: Estimates of Isoprene and Monoterpene Emission Rates in Plants, Bot. Gaz., 143, 304-310, https://doi.org/10.1086/botanicalgazette.143.3.2474826, 1982.

Fountoukis, C. and Nenes, A.: ISORROPIA II: a computationally efficient thermodynamic equilibrium model for $\mathrm{K}^{+}$ $\mathrm{Ca}^{2+}-\mathrm{Mg}^{2+}-\mathrm{NH}_{4}^{+}-\mathrm{Na}^{+}-\mathrm{SO}_{4}^{2-}-\mathrm{NO}_{3}^{-}-\mathrm{Cl}^{-}-\mathrm{H}_{2} \mathrm{O}$ aerosols, Atmos. Chem. Phys., 7, 4639-4659, https://doi.org/10.5194/acp-74639-2007, 2007.

González-Orozco, C. E., Pollock, L. J., Thornhill, A. H., Mishler, B. D., Knerr, N., Laffan, S. W., Miller, J. T., Rosauer, D. F., Faith, D. P., Nipperess, D. A., Kujala, H., Linke, S., Butt, N., Külheim, C., Crisp, M. D., and Gruber, B.: Phylogenetic approaches reveal biodiversity threats under climate change, Nat. Clim. Change, 6, 1110-1114, https://doi.org/10.1038/nclimate3126, 2016.

Guenther, A. B., Zimmerman, P. R., Harley, P. C., Monson, R. K., and Fall, R.: Isoprene and monoterpene emission rate variability: Model evaluations and sensitivity analyses, J. Geophys. Res.Atmos., 98, 12609-12617, https://doi.org/10.1029/93JD00527, 1993.

Guenther, A. B., Jiang, X., Heald, C. L., Sakulyanontvittaya, T., Duhl, T., Emmons, L. K., and Wang, X.: The Model of Emissions of Gases and Aerosols from Nature version 2.1 (MEGAN2.1): an extended and updated framework for modeling biogenic emissions, Geosci. Model Dev., 5, 1471-1492, https://doi.org/10.5194/gmd-5-1471-2012, 2012.

He, C., Murray, F., and Lyons, T.: Monoterpene and isoprene emissions from 15 Eucalyptus species in Australia, Atmos. Environ., 34, 645-655, https://doi.org/10.1016/S1352-2310(99)00219-8, 2000.

Heald, C. L., Wilkinson, M. J., Monson, R. K., Alo, C. A., Wang, G., and Guenther, A.: Response of isoprene emission to ambient $\mathrm{CO}_{2}$ changes and implications for global budgets, Glob. Change Biol., 15, 1127-1140, https://doi.org/10.1111/j.13652486.2008.01802.x, 2009.

Jiang, M., Medlyn, B. E., Drake, J. E., Duursma, R. A., Anderson, I. C., Barton, C. V. M., Boer, M. M., Carrillo, Y., CastañedaGómez, L., Collins, L., Crous, K. Y., De Kauwe, M. G., dos Santos, B. M., Emmerson, K. M., Facey, S. L., Gherlenda, A. N., Gimeno, T. E., Hasegawa, S., Johnson, S. N., Kännaste, A., Macdonald, C. A., Mahmud, K., Moore, B. D., Nazaries, L., Neilson, E. H. J., Nielsen, U. N., Niinemets, Ü., Noh, N. J., Ochoa-Hueso, R., Pathare, V. S., Pendall, E., Pihlblad, J., Piñeiro, J., Powell, J. R., Power, S. A., Reich, P. B., Renchon, A. A., Riegler, M., Rinnan, R., Rymer, P. D., Salomón, R. L., Singh, B. K., Smith, B., Tjoelker, M. G., Walker, J. K. M., Wujeska-Klause, A., Yang, J., Zaehle, S., and Ellsworth, D. S.: The fate of carbon in a mature forest under carbon dioxide enrichment, Nature, 580, 227-231, https://doi.org/10.1038/s41586-020-2128-9, 2020.

Karkik, J. and Winer, A.: Measured isoprene emission rates of plants in California landscapes: comparison to estimates from taxonomic relationships, Atmos. Environ., 35, 1123-1131, https://doi.org/10.1016/S1352-2310(00)00258-2, 2001.

Kesselmeier, J. and Staudt, M.: Biogenic Volatile Organic Compounds (VOC): An Overview on Emission,
Physiology and Ecology, J. Atmos. Chem., 33, 23-88, https://doi.org/10.1023/A:1006127516791, 1999.

Keywood, M., Selleck, P., Reisen, F., Cohen, D., Chambers, S., Cheng, M., Cope, M., Crumeyrolle, S., Dunne, E., Emmerson, K., Fedele, R., Galbally, I., Gillett, R., Griffiths, A., Guerette, E.-A., Harnwell, J., Humphries, R., Lawson, S., Miljevic, B., Molloy, S., Powell, J., Simmons, J., Ristovski, Z., and Ward, J.: Comprehensive aerosol and gas data set from the Sydney Particle Study, Earth Syst. Sci. Data, 11, 1883-1903, https://doi.org/10.5194/essd-11-1883-2019, 2019.

Keywood, M. D., Hibberd, M. H., and Emmerson, K. M.: Australia: State of the environment 2016 - Atmosphere, independent report to the Australian Government Minister for the Environment and Energy, Australian Government Department of the Environment and Energy, Canberra, https://doi.org/10.4226/94/58b65c70bc372, 2016.

Loreto, F. and Fineschi, S.: Reconciling functions and evolution of isoprene emission in higher plants, New Phytol., 206, 578-582, https://doi.org/10.1111/nph.13242, 2015.

McGregor, J. L. and Dix, M. R.: An updated description of the Conformal-Cubic Atmospheric Model in High Resolution Simulation of the Atmosphere and Ocean, edited by: Hamilton, K. and Ohfuchi, W., 51-76, Springer, 2008.

Millet, D. B., Baasandorj, M., Hu, L., Mitroo, D., Turner, J., and Williams, B. J.: Nighttime Chemistry and Morning Isoprene Can Drive Urban Ozone Downwind of a Major Deciduous Forest, Environ. Sci. Technol., 50, 4335-4342, https://doi.org/10.1021/acs.est.5b06367, 2016.

NASA LP DAAC: MODIS leaf area index data product was retrieved from MCD15A2 version 4 from the online Data Pool, courtesy of the NASA Land Processes Distributed Active Archive Center (LP DAAC), USGS/Earth Resources Observation and Science (EROS) Center, Sioux Falls, South Dakota, available at: https://lpdaac.usgs.gov/data_access/data_pool, last access: June 2004.

Nelson, P. F., Nancarrow, P. C., Haliburton, B., Tibbet, A. R., Chase, D., and Trieu, T.: Biogenic emissions from trees and grasses, CSIRO investigation Report ET/IR297, Tech. rep., 2000.

Niinemets, $\ddot{U}$. and Sun, Z.: How light, temperature, and measurement and growth $\left[\mathrm{CO}_{2}\right]$ interactively control isoprene emission in hybrid aspen, J. Exp. Bot., 66, 841-51, https://doi.org/10.1093/jxb/eru443, 2015.

Niinemets, Ü., Arneth, A., Kuhn, U., Monson, R. K., Peñuelas, J., and Staudt, M.: The emission factor of volatile isoprenoids: stress, acclimation, and developmental responses, Biogeosciences, 7, 2203-2223, https://doi.org/10.5194/bg-7-22032010, 2010.

Paton-Walsh, C., Guérette, É.-A., Kubistin, D., Humphries, R., Wilson, S. R., Dominick, D., Galbally, I., Buchholz, R., Bhujel, M., Chambers, S., Cheng, M., Cope, M., Davy, P., Emmerson, K., Griffith, D. W. T., Griffiths, A., Keywood, M., Lawson, S., Molloy, S., Rea, G., Selleck, P., Shi, X., Simmons, J., and Velazco, V.: The MUMBA campaign: measurements of urban, marine and biogenic air, Earth Syst. Sci. Data, 9, 349-362, https://doi.org/10.5194/essd-9-349-2017, 2017.

Paton-Walsh, C., Guérette, E.-A., Emmerson, K., Cope, M., Kubistin, D., Humphries, R., Wilson, S., Buchholz, R., Jones, N. B., Griffith, D. W. T., Dominick, D., Galbally, I., Keywood, M., Lawson, S., Harnwell, J., Ward, J., Griffiths, 
A., and Chambers, S.: Urban Air Quality in a Coastal City: Wollongong during the MUMBA Campaign, Atmosphere, 9, 500, https://doi.org/10.3390/atmos9120500, 2018.

Paton-Walsh, C., Rayner, P., Simmons, J., Fiddes, S., Schofield, R., Bridgman, H., Beaupark, S., Broome, R., Chambers, S., Chang, L.-C., Cope, M., Cowie, C., Desservettaz, M., Dominick, D., Emmerson, K., Forehead, H., Galbally, I., Griffiths, A., Guérette, E.A., Haynes, A., Heyworth, J., Jalaludin, B., Kan, R., Keywood, M., Monk, K., Morgan, G., Nguyen Duc, H., Phillips, F., Popek, R., Scorgie, Y., Silver, J., Utembe, S., Wadlow, I., Wilson, S., and Zhang, Y.: A Clean Air Plan for Sydney: An Overview of the Special Issue on Air Quality in New South Wales, Atmosphere, 10, 774, https://doi.org/10.3390/atmos10120774, 2019.

Pearcy, R. W.: Sunflecks and Photosynthesis in Plant Canopies, Annu. Rev. Plant Phys., 41, 421-453, https://doi.org/10.1146/annurev.pp.41.060190.002225, 1990.

Peñuelas, J. and Munné-Bosch, S.: Isoprenoids: an evolutionary pool for photoprotection, Trends Plant Sci.e, 10, 166-169, https://doi.org/10.1016/j.tplants.2005.02.005, 2005.

Physick, B., Edwards, M., and Cope, M.: A Screening Procedure for Monitoring Ozone and Nitrogen Dioxide in "Small-to Mediumsized" Cities: Phase II application of the procedure, CSIRO, Australia, Tech. rep., CSIRO Marine and Atmospheric Research, 2002

Sharkey, T. D. and Monson, R. K.: The future of isoprene emission from leaves, canopies and landscapes, Plant Cell Environ., 37, 1727-1740, https://doi.org/10.1111/pce.12289, 2014.

Sharkey, T. D. and Monson, R. K.: Isoprene research - 60 years later, the biology is still enigmatic, Plant Cell Environ., 40, 16711678, https://doi.org/10.1111/pce.12930, 2017.

Sharkey, T. D., Wiberley, A. E., and Donohue, A. R.: Isoprene Emission from Plants: Why and How, Ann. Bot., 101, 5-18, https://doi.org/10.1093/aob/mcm240, 2008.

Shrivastava, M. K., Lane, T. E., Donahue, N. M., Pandis, S. N., and Robinson, A. L.: Effects of gas particle partitioning and aging of primary emissions on urban and regional organic aerosol concentrations, J. Geophys. Res.-Atmos., 113, D18301, https://doi.org/10.1029/2007JD009735, 2008.
Street, R. A., Hewitt, C. N., and Mennicken, S.: Isoprene and monoterpene emissions from a eucalyptus plantation in Portugal, J. Geophys. Res.-Atmos., 102, 15875-15887, https://doi.org/10.1029/97JD00010, 1997.

Taipale, R., Ruuskanen, T. M., Rinne, J., Kajos, M. K., Hakola, H., Pohja, T., and Kulmala, M.: Technical Note: Quantitative long-term measurements of VOC concentrations by PTR-MS - measurement, calibration, and volume mixing ratio calculation methods, Atmos. Chem. Phys., 8, 6681-6698, https://doi.org/10.5194/acp-8-6681-2008, 2008.

Tsimpidi, A. P., Karydis, V. A., Zavala, M., Lei, W., Molina, L., Ulbrich, I. M., Jimenez, J. L., and Pandis, S. N.: Evaluation of the volatility basis-set approach for the simulation of organic aerosol formation in the Mexico City metropolitan area, Atmos. Chem. Phys., 10, 525-546, https://doi.org/10.5194/acp-10-5252010, 2010.

Utembe, S. R., Rayner, P. J., Silver, J. D., Guérette, E.-A., Fisher, J. A., Emmerson, K. M., Cope, M., Paton-Walsh, C., Griffiths, A. D., Duc, H., Monk, K., and Scorgie, Y.: Hot Summers: Effect of Extreme Temperatures on Ozone in Sydney, Australia, Atmosphere, 9, 466, https://doi.org/10.3390/atmos9120466, 2018.

van Vuuren, D. P., Edmonds, J., Kainuma, M., Riahi, K., Thomson, A., Hibbard, K., Hurtt, G. C., Kram, T., Krey, V., Lamarque, J.-F., Masui, T., Meinshausen, M., Nakicenovic, N., Smith, S. J., and Rose, S. K.: The representative concentration pathways: an overview, Climatic Change, 109, 5, https://doi.org/10.1007/s10584-011-0148-z, 2011.

Yáñez-Serrano, A. M., Mahlau, L., Fasbender, L., Byron, J., Williams, J., Kreuzwieser, J., and Werner, C.: Heat stress increases the use of cytosolic pyruvate for isoprene biosynthesis, J. Exp. Bot., 70, 5827-5838, https://doi.org/10.1093/jxb/erz353, 2019. 